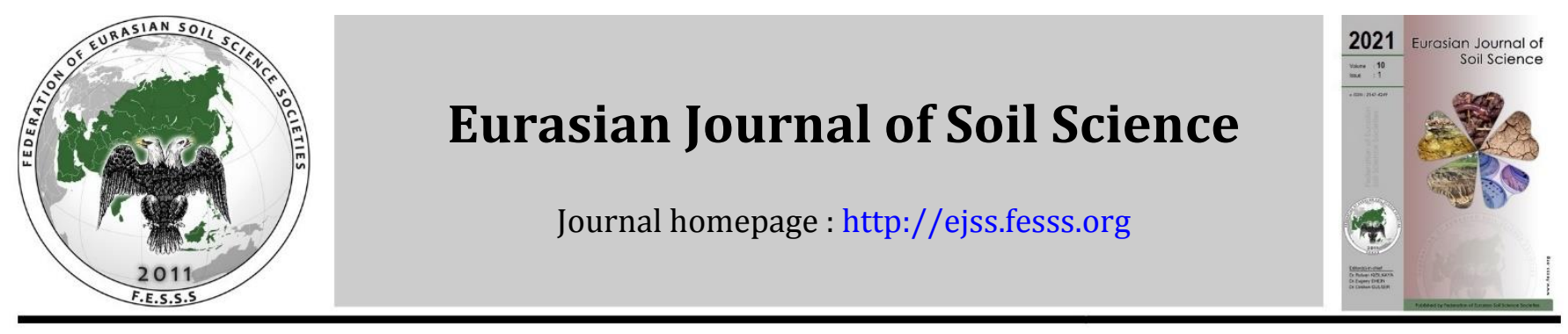

\title{
Transformation of plant and soil covers of the Botanical nature monument "Pine forest near Venetsiya village" (Russia) as a result of a windfall
}

\author{
Ruslan Suleymanov a,b*, Mikhail Yakimov b, Peter Liebelt c, Pavel Shirokikh a, \\ Azamat Suleymanov a, Evgeny Abakumov d, Ilgiza Adelmurzina b, \\ Elvera Bakieva ${ }^{b}$, Ilgiz Asylbaev $f$ \\ a Ufa Institute of Biology, Ufa Federal Research Center Russian Academy of Sciences, Ufa, Russia \\ ${ }^{\mathrm{b}}$ Bashkir State University, Faculty of Earth Sciences and Tourism, Department of Geodesy, Cartography and \\ Geographical Information Systems, Ufa, Russia \\ c Martin Luther University Halle-Wittenberg, Institute of Geosciences and Geography, Halle (Saale), Germany \\ ${ }^{d}$ Saint Petersburg State University, Faculty of Biology, Department of Applied Ecology, Saint Petersburg, Russia \\ e Bashkir State Agrarian University, Faculty of Agrotechnologies and Forestry, Department of Soil Science,
} Agrochemistry and Precision Agriculture, Ufa, Russia

\section{Article Info}

Received : 16.10 .2020

Accepted : 18.04 .2021

Available online : 23.04 .2021

\section{Author(s)}

R. Suleymanov *

M. Yakimov

P. Liebelt

P. Shirokikh

A. Suleymanov

E. Abakumov

I. Adelmurzina

E. Bakieva

I. Asylbaev

${ }^{*}$ Corresponding author

\section{Abstract}

The article presents the results of complex research (research was conducted in 2019) of the Botanical natural monument territory "Pine forest near Venetsiya village" (Russia). In 2007, part of the nature monument territory was destroyed by a hurricane, resulting in massive windfall. The purpose of the research was to study the processes of evolution of natural complexes (vegetation and soil cover) in the areas affected by the hurricane. Classification of vegetation was done according to the Braun-Blanquet and Kopečký and Hejný approaches. NDVI (Normalized Difference Vegetation Index) was used to estimate the amount of photosynthetically active biomass. Changes in morphological, physical and chemical properties were studied in the soil cover. The conducted research showed that the vegetation of the natural monument is represented by relict pine and broad-leaved pine forests. Under the pine canopy linden and birch are dominated. In the herb layer grow in various combinations of nemoral and boreal species. Soil cover is represented by Gray-humus (Umbric Luvisol). There is a strong transformation of vegetation in the areas damaged by the hurricane in 12 years (2007-2019). There is an active formation of highly productive herbaceous vegetation and renewal of deciduous stands, which leads to an increase in biomass (confirmed by changes in NDVI). The terminal stage of the restoration succession will be the formation of secondary deciduous and mixed nemoral forests. The active development of grass vegetation leads to the formation of a sod horizon on the surface of the soil with a thickness of about $14 \mathrm{~cm}$. There is also an increase in the content of organic carbon, alkaline-hydrolyzable nitrogen and mobile phosphorus, the value of electrical resistivity increases and acidification of the soil solution.

Keywords: Pine forest, soil properties, vegetation type, windfall.

(c) 2021 Federation of Eurasian Soil Science Societies. All rights reserved

\section{Introduction}

One of the negative impacts of global climate change is the occurrence of wind storms such as hurricanes and tornado. According to forecasts, as the average global temperature rises, their intensity and strength will

https://doi.org/10.18393/ejss.926882

http://ejss.fesss.org/10.18393/ejss.926882 
only increase (Long et al., 2018; Santoro and D'Amato, 2019). They affect not only coastal areas and islands, but also inland areas (Chernokulsky and Shikhov, 2018; Sahoo et al., 2019; De Beurs et al., 2019; Ezer, 2020). Currently, hurricanes, for example, have been appearing in new places where they've never met before (Hoffmann et al., 2018; Barrett et al., 2020). With great destructive power, wind storms cause huge loss of life and property damage (Moore, 2017; Diaz and Joseph, 2019; Cui and Caracoglia, 2019). They also have a strong impact on natural complexes, such as coastal wetlands, (Majidzadeh et al., 2020; Mo et al., 2020), tropical dry forests (Novais et al., 2020), deciduous forests (Santoro and D'Amato, 2019), agricultural land (Strader et al., 2018; Baker et al., 2020) and sandy sediments (Meixler, 2017).

Recently, cases of hurricanes have become more frequent in Russia, including the Republic of Bashkortostan. They influence the forests, which leads to the formation of windfalls. As a result of sharp change of ecological factors, determining the functioning of forest ecosystems, change of structure of plant communities and correlation of dominance of various herbaceous species of plants in the ground cover is observed (Shirokikh et al., 2017; Shikhov and Chernokulsky, 2018). Thus, there is a need to study the processes of evolution of natural complexes (vegetation and soil cover) destroyed as a result of the hurricane. Studies will allow to determine the direction of their development and assess the potential of self-recovery in the same natural and climatic conditions to develop methods for their restoration.

\section{Material and Methods}

The research was conducted on the territory of the Botanical nature monument of regional importance "Pine forest near Venetsiya village". The site is located in the northwestern part of the Republic of Bashkortostan (Dyurtyuli city, Venetsiya village) on the right bank of the Belaya River (Figure 1). The natural monument was created on July 17, 1965, and has scientific, environmental, and recreational significance. The total area is 490.0 hectares (The Register..., 2016).

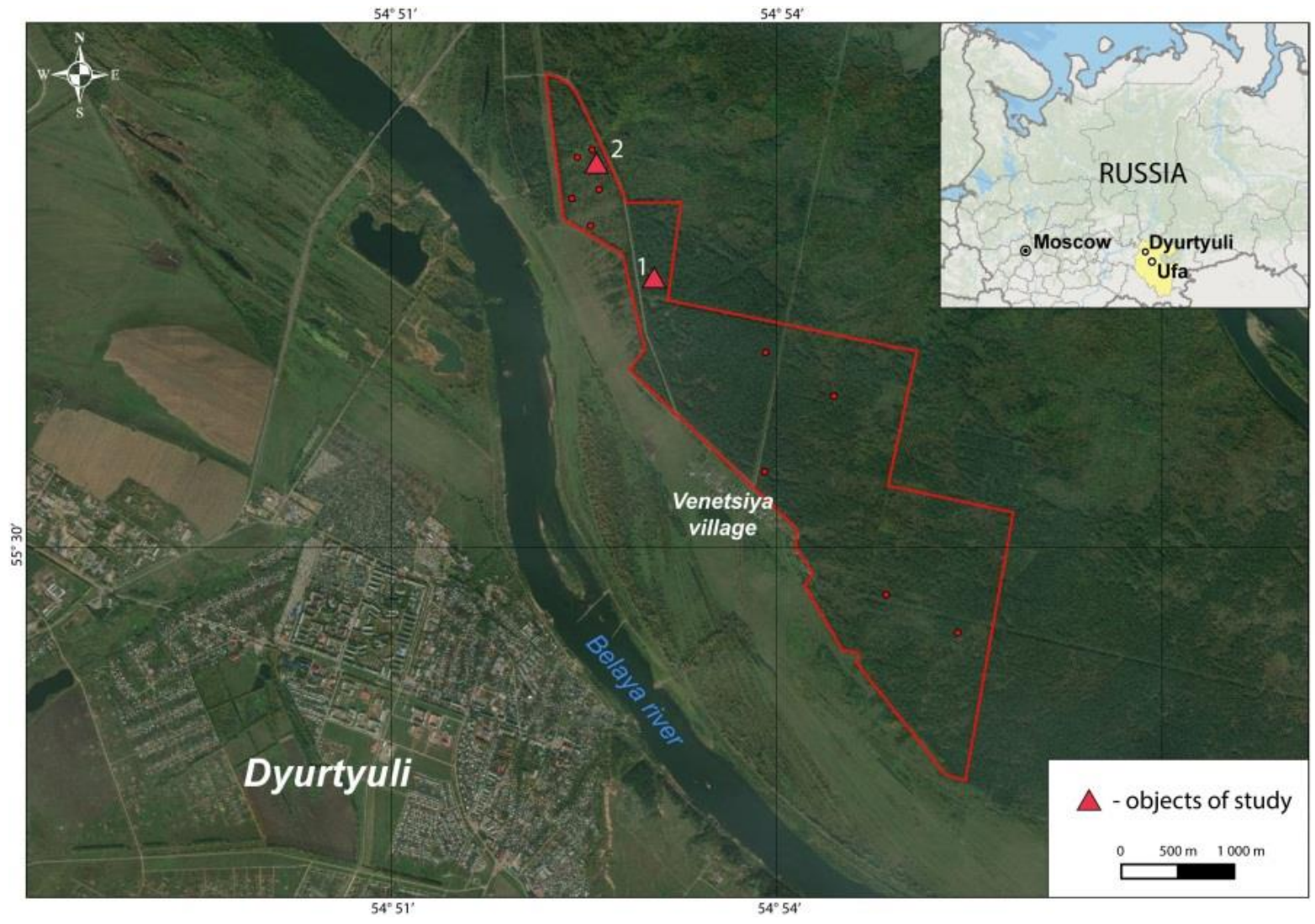

Figure 1. Map of the study area (image source: www.google.com/intl/ru/earth).

Note: the basic soil pits are shown as triangles, the small soil pits as circles

The natural complex of the monument is represented by relict pine and broad-leaved pine forests on the sandy terraces of the Belaya River. Dominated by bilberry, lingonberry, and nemoral pine-deciduous forests. Tree stand are highly productive, the average age of pines is 45-80 years, and individual stands reach 100 years or more. They belong to the green zone and forbidden lanes. Under the pine canopy linden and birch are dominated. In the undergrowth are common Euonymus verrucosa, Lonicera xylosteum, Coryllus avellana, Sorbus aucuparia and Padus avium. In the herb layer grow in various combinations of nemoral and boreal species. There is a rare species - Chimaphila umbellata (L.) W.P.C. Barton, included in the Red book of the 
Republic of Bashkortostan (2011). Unfortunately, in 2007, a significant part of the pine forests was destroyed by a hurricane, so it is necessary to adjust the area and borders of the natural monument (Cadastral..., 2019).

The geomorphological area is located on the III floodplain terrace of the Belaya River with heights of 70-90 $\mathrm{m}$. The area is composed of sands, sandy loams and loams of yellowish-brown Upper Quaternary time (Kadilnikov, 1964).

According to the physical and geographical regionalization, this area belongs to the forest natural and climatic zone of the coniferous-broadleaved forest subzone. The climate at study area characterized as moderate continental with average humidity or as warm-summer humid continental (Dfb) by the Köppen climate classification (Beck et al., 2018). The average annual temperature is $+1.7^{\circ} \mathrm{C}$, the average temperature in January is $-14.9^{\circ} \mathrm{C}$, the average temperature in July is $+18^{\circ} \mathrm{C}$, the duration of the frost-free period is $88-100$ days, the annual rainfall is $515-580 \mathrm{~mm}$, the height of snow cover is $30-50 \mathrm{~cm}$ (Kadilnikov, 1964).

Research has been was conducted at two key sites. The first site it is the area of the botanical nature monument that was not affected by the hurricane (nature area), the second site it is the area that was affected by the hurricane. The study of vegetation and soil cover was conducted in the studied areas.

Moreover, the geobotanical description was performed on plots where soil pits were located. Geobotanical releves and classification of vegetation was done according to the Braun-Blanquet (Westhoff and van der Maarel, 1978) and Kopečký and Hejný (1974) approaches. The syntaxon names follow the International Code of Phytosociological Nomenclature (Weber et al., 2000). The names of plant species are given by the species list of Czerepanov (1995).

To estimate the amount of photosynthetically active biomass was used the Normalized Difference Vegetation Index (NDVI). The calculation was based on space images from Landsat 5 (L5) and Landsat 8 (L8) satellites with a spatial resolution of $30 \mathrm{~m}$, received from the U.S. Geological Survey archive (https://earthexplorer.usgs.gov/). Imaging dates: 16 July 2006 (L5 satellite); 12 June 2008 (L5 satellite); 13 August 2013 (L8 satellite); 2 June 2019 (L8 satellite). NDVI Index calculations were performed using ENVI 5.2 software package. The final thematic maps and area calculations were made in MapInfo 12.5 geographic information system.

Soil classification, diagnostics of the soil profile and genetic horizons ware carried out taking into account the substantive genetic classification (Shishov et al., 2004). Basic profiles (1D-2019 and 2D-2019) and small pits (five each) at key sites were laid to most fully reflect the state of natural complexes. Soil samples for chemical analysis were taken from genetic horizons. Field soil moisture content was determined in the field by using Soil Moisture Sensor SM 150, soil penetration was measured from the soil surface to a depth of 45 $\mathrm{cm}$ in $2.5 \mathrm{~cm}$ intervals by using Soil Compaction Meter FieldScout SC 900 equipped a metal rod with a cone (size 1/2 inch). Electrical resistivity was determined using the Landmapper ERM-03 instrument (Pozdnyakov, 2008). Soil temperature was measured by soil thermometer AM-6. Measurement of illumination on the soil surface was carried out with a portable lux meter CEM DT-86.

Chemical analyses were carried out using standard methods reported in Arinushkina (1970) and Sokolov (1975): the total organic carbon using the Tyurin method with termination according to Orlov and Grindel (Arinushkina, 1970); alkaline hydrolyzable nitrogen, according to Cornfield (Sokolov, 1975); available phosphorus according to Chirikov (Sokolov, 1975); soil reaction by potentiometry (Arinushkina, 1970). The statistical analyses were performed by using MS Excel 2007.

\section{Results and Discussion}

The soil cover was studied and the soil section № 1D-2019 was made in the area without the impact of the hurricane. In this territory are distributed the nemoral pine-deciduous forests. According to the BraunBlanquet approaches this forests belonging of the association Tilio cordatae-Pinetum sylvestris Martynenko 2009 prov. (suballiance Tilio-Pinenion Martynenko et Shirokikh 2009 prov. alliance Aconito lycoctoni-Tilion cordatae Solomeshch et Grigoriev in Willner et al. 2016, order Carpinetalia betuli P.Fukarek 1968 class Carpino-Fagetea sylvaticae Jakucs ex Passarge 1968).

The tree stand is well developed. In the first tree layer is dominated by pine (Pinus sylvestris), which has a projective cover of $40 \%$ with an average height of 24-26 m and a trunk diameter of 28-34 cm. Under the pine canopy, the species of broad-leaved trees are dominated: linden (Tilia cordata), maple (Acer platanoides), and elm (Ulmus glabra). The projective cover varies from 25 to $40 \%$ and the height does not exceed $6 \mathrm{~m}$. In the undergrowth are common Coryllus avellana, Sorbus aucuparia, and Padus avium. 
The shrub layer is almost undeveloped and is represented by small specimens of Lonicera xylosteum, Euonymus verrucosa, Rosa majalis, Rubus idaeus, and Daphne mezereum.

As a result of the strong shading of the tree canopy of linden, maple, and elm, the herb layer is poorly developed. The total projective cover of the herb layer varies from 5 to $20 \%$, with an average of $15 \%$ in depending of shading of trees. The main cover of the herb layer is created by the Pteridium aquilinum, Calamagrostis arundinacea, Brachypodium pinnatum, Aegopodium podagraria. With high frequency are present the species of nemoral broad-leaved forests (Melica nutans, Fragaria vesca, Viola mirabilis, Pulmonaria obscura, Glechoma hederacea, Lathyrus vernus, Stellaria holostea etc). The average height of the herb layer varies from 20 to $40 \mathrm{~cm}$.

In the area affected by the hurricane the soil cover was studied and the soil section № 2D-2019 was made. This area represents of vegetation that was formed after the mass windfall of nemoral pine-deciduous forests of ass. Tilio cordatae-Pinetum sylvestris, and subsequently the felling and transportation of broken trees, as well as the burning of felling residues.

On the most of the territory are distributed by meadows with high projective cover $(70-85 \%)$. In the herb layer dominated by rhizome cereals: Poa angustifolia, Poa pratensis, Agrostis tenuis, Calamagrostis epigeios. The typical species of meadows (Achillea millefolium, Hypericum perforatum, Galium album, Vicia cracca, Lathyrus pratensis, Linaria vulgaris, Filipendula vulgaris and others) and ruderal vegetation (Artemisia absinthium, Taraxacum officianle, Picris hieracioides, Cirsium setosum) are also present in the floristic composition.

Among the meadow vegetation, individual specimens or small groups are distributed of different age of trees, represented by broad-leaved and small-leaved species. They have been preserved in the undergrowth after a hurricane and logging. The projected cover of the trees varies from 5 to $50 \%$ with a height of $0,5-4,0$ $\mathrm{m}$. The main projective cover is mainly created by birch (Betula pendula) and pine (Pinus sylvestris). With less abundance, linden (Tilia cordata) and elm (Ulmus glabra) are present in tree composition. Rarely meet the maple (Acer platanoides), willow (Salix caprea), rowan (Sorbus aucuparia), and bird cherry (Padus avium). As a rule, under the canopy of trees, the herbage is very sparse and is represented mainly by meadow species.

According to the Braun-Blanquet and Kopečký and Hejný approaches, this community can be belonging to the basal community Calamageostis epigeios-Tilia cordata [Festucion pratensis/Aconito-Tilion] of alliance Festucion pratensis Sipajlova et al. 1985 (order Arrhenatheretalia R. Tx. 1931, class Molinio-Arrhenatheretea R. Tx. 1937).

To study the dynamics of biomass and vegetation cover over time it is widely used the NDVI. (Pisek et al., 2015; Chakraborty et al., 2018; Fern et al., 2018). Areas with different levels of bioproductivity can be identified using the NDVI too (Peng et al., 2019). Riihimäki et al. (2017) notes that the highest NDVI values and biomass are usually found in areas with low altitudes and high levels of solar radiation on the slopes of the south and southwest exposure. Landsat data have been widely used to obtain NDVI because of their long archive and relatively high spatial resolution (Zhu and Liu, 2015; Tucker et al., 2020).

Table 1. Dynamics of area change under different vegetation types

\begin{tabular}{|c|c|c|c|c|c|c|c|c|c|}
\hline \multirow{2}{*}{ NDVI* } & \multicolumn{2}{|c|}{2006 year } & \multirow{2}{*}{2007 year } & \multicolumn{2}{|c|}{2008 year } & \multicolumn{2}{|c|}{2014 year } & \multicolumn{2}{|c|}{2019 year } \\
\hline & $\mathrm{S}, \mathrm{km}^{2}$ & $\%$ & & $\mathrm{~S}, \mathrm{~km}^{2}$ & $\%$ & $\mathrm{~S}, \mathrm{~km}^{2}$ & $\%$ & $\mathrm{~S}, \mathrm{~km}^{2}$ & $\%$ \\
\hline$-1-0$ & 0.098 & 1.6 & & 0.562 & 9.4 & 0.236 & 4.0 & 0.135 & 2.3 \\
\hline $0-0.1$ & 0.077 & 1.3 & & 0.250 & 4.2 & 0.242 & 4.1 & 0.110 & 1.8 \\
\hline $0.1-0.2$ & 0.124 & 2.1 & & 0.387 & 6.5 & 0.747 & 12.5 & 0.517 & 8.7 \\
\hline $0.2-0.3$ & 0.433 & 7.3 & & 0.692 & 11.6 & 1.557 & 26.1 & 1.092 & 18.3 \\
\hline $0.3-0.4$ & 2.376 & 39.8 & ت & 1.606 & 26.9 & 1.267 & 21.2 & 1.115 & 18.7 \\
\hline $0.4-0.5$ & 1.825 & 30.6 & : & 1.348 & 22.6 & 0.856 & 14.3 & 0.914 & 15.3 \\
\hline $0.5-0.6$ & 0.450 & 7.5 & $\Xi$ & 0.578 & 9.7 & 0.551 & 9.2 & 0.685 & 11.5 \\
\hline $0.6-0.7$ & 0.247 & 4.1 & & 0.262 & 4.4 & 0.275 & 4.6 & 0.534 & 9.0 \\
\hline $0.7-0.8$ & 0.155 & 2.6 & & 0.136 & 2.3 & 0.117 & 2.0 & 0.457 & 7.7 \\
\hline $0.8-1$ & 0.180 & 3.0 & & 0.144 & 2.4 & 0.117 & 2.0 & 0.406 & 6.8 \\
\hline Total & 5.965 & 100.0 & & 5.965 & 100.0 & 5.965 & 100.0 & 5.965 & 100.0 \\
\hline
\end{tabular}

*Note: NDVI values: -1.0-0.1 - bare soil, roads; 0.1-0.3 - thin meadow vegetation; 0.3-0.5 - pine forest with a dense woodland; 0.5-0.6 - sparse pine forest dominated by broad-leaved species; 0.6-1.0 - broad-leaved forests 
Before the hurricane in 2007 , more than $80 \%$ of the research area was occupied by light coniferous and light coniferous-broad-leaved forests, so the main contribution to the formation of NDVI values is made by the standing pine, whose crowns occupy a large area (Table 1, Figure 2). The rest of the territory is occupied by mixed broad-leaved forests and small areas of meadow vegetation. In 2007, a storm destroyed part of the pine forests on the monument's territory. This was followed by clearing the area of fallen trees, which resulted in additional damage to the surface layers and a sharp decline in phytomass. Since 2009, in some areas affected by the windfall, the removal of the sod layer and planting of pine seedlings were carried out, so by 2014 compared to 2008 there was a slight increase in areas with bare soil and thinned vegetation (Figure 2). However, much of the area affected by the hurricane was left to natural recovery. Later, in place of windfalls, ruderal and meadow vegetation with prevailing cereals was formed. And in their place, the renewal of broad-leaved (Tilia cordata, Ulmus glabra, Acer platanoides, Padus avium) and small-leaved (Betula pendula) trees began. This is confirmed by the results of the NDVI analysis, which shows a gradual increase in phytomass and a decrease in the areas of disturbed sites and thinned weed-meadow vegetation (Figure 2). In 2019, areas with NDVI values between 0.5 and 1.0 are already above the 2006 values. Such differences are explained by the lower biomass and photosynthetic activity of pine forests compared to meadow vegetation and the emerging secondary broadleaved forests (Chernetskiy et al., 2011; Adamovich et al., 2018; Pisman et al., 2018).

Table 2. Description of soil profile under a pine forest

$\begin{array}{ll}\text { Profile Name: } & \text { 1D-2019 } \\ \text { Location: } & \text { N 55.519208, E 54.884311 }\end{array}$

Area Description: Pine forest, the small slope of the southern exposition.

Altitude: $\quad 86 \mathrm{~m}$ above sea level

Horizon: $\quad 0,0-4 \mathrm{~cm}$. Forest litter of various degrees of decomposition, fir-needles, cones, leaves, tree branches.

AY, 4-16 cm. Dark brown, slightly wet, unstructured, sandy loam, plant, and tree roots, border to the next horizon is interfingering.

C, 16-50 cm. Light brown, wet, unstructured, sandy loam, crumbly soil structure, plant and tree roots.

Soil Name: Gray-humus (Umbric Luvisol)
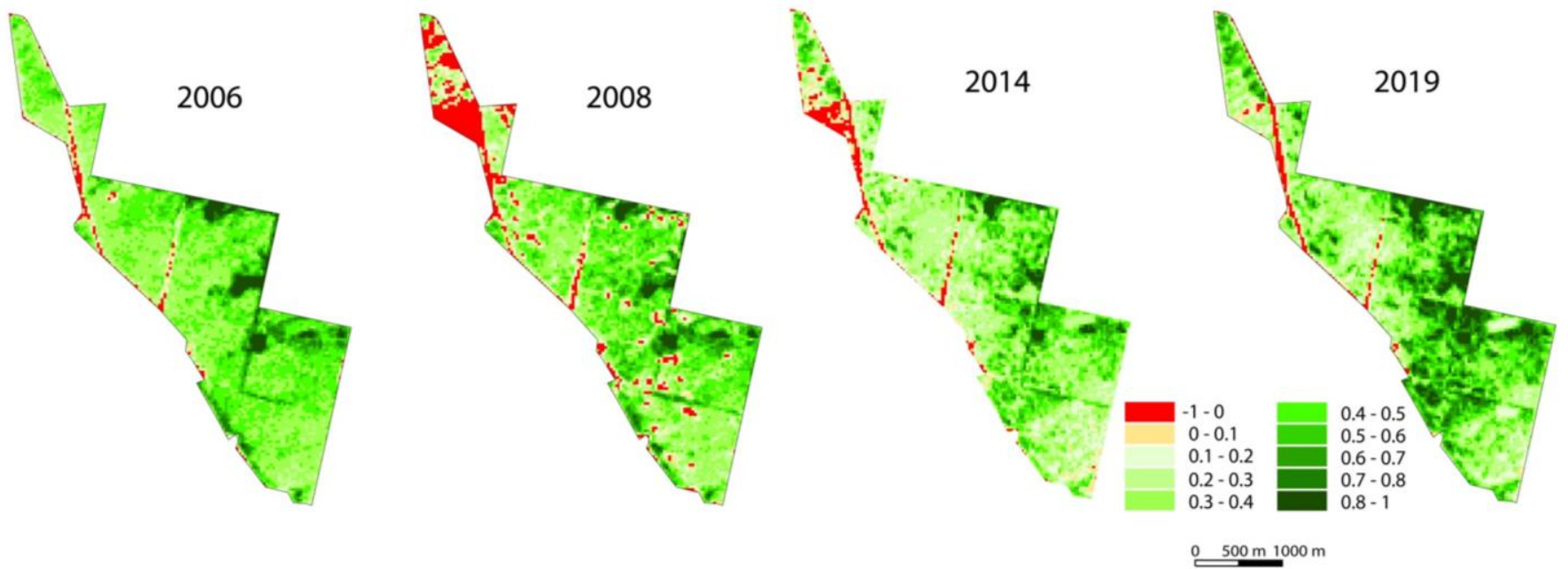

Figure 2. Change of NDVI values in the territory botanical nature monument «Pine forest near Venetsiya village» (2006, 2008, 2014, 2019 - years; NDVI values: -1.0-0.1 - bare soil, roads; 0.1-0.3 - thin meadow vegetation; 0.3-0.5 - pine forest with a dense woodland; 0.5-0.6 - sparse pine forest dominated by broad-leaved species; 0.6-1.0 - broad-leaved forests)

Active renewal of herbal and woody vegetation led to formation of the sod layer at the soil and changes in its physical and chemical characteristics. To study the changes in soil properties in the areas affected by the hurricane, we give their morphological description. The morphological description of the studied soils is given in Table 2, 3.

The analysis of morphological properties of soils shows that in the post-hurricane areas as a result of their overgrowth with meadow motley grass the formation of sod horizon with a capacity of approximately $14 \mathrm{~cm}$ occurred. These areas are also characterized by a high level of illumination (10140 lx) compared to the areas occupied by forest $(621 \mathrm{~lx})$. Intensive insolation promotes greater warming of the soil profile in the post- 
hurricane area (temperature approximately $2^{\circ} \mathrm{C}$ higher than in the area under the forest), which causes intensive evaporation of soil moisture (field moisture in the sod horizon is only 5.2\%) (Table 4). Determination of soil density using penetrometer showed that in the studied areas the values of resistance to penetration into the soil of the metal rod with a cone at the end to a depth of $45 \mathrm{~cm}$ are within the normal range (0-1379 $\mathrm{kPa}$ ) for root system growth. Differences in density between soil profiles are insignificant and are caused by spatial heterogeneity of the territory soil cover (Figure 3 ).

Table 3. Description of soil profile in the area affected by the hurricane

\begin{tabular}{ll}
\hline Profile Name: & 2D-2019 \\
Location: & N 55.528133, E 54.873336 \\
Area Description: & Windfall, the small slope of the southern exposition \\
Altitude: & $73 \mathrm{~m}$ above sea level \\
Horizon: & AO, 0-14 cm. Gray, slightly wet, sandy loam, Soil structure in the form of powder and lumps, \\
& densely rooted, the transition to the next horizon is gradual. \\
& AY, 14-26 cm. Dark Brown, slightly wet, unstructured, sandy loam, plant and tree roots, border \\
& to the next horizon is interfingering. \\
& C, $26-60 \mathrm{~cm}$. Light brown, wet, unstructured, sandy loam, crumbly soil structure, plant and tree \\
& roots. \\
Soil Name: & Gray-humus (Umbric Luvisol)
\end{tabular}

Table 4. Physical properties of soils (field definition)

\begin{tabular}{lcccc}
\hline \multirow{2}{*}{ Horizon, depth, cm } & Field moisture & Electrical resistivity & Temperature & Illuminance (on soil surface) \\
\cline { 2 - 4 } & $\%$ & Ohm m & ${ }^{\circ} \mathrm{C}$ & $\mathrm{lx}$ \\
AY, $4-16$ & $18.2 \pm 3.9$ & Soil Profile 1D-2019 & \\
C, $16-50$ & $11.6 \pm 0.9$ & $1373 \pm 754$ & $15.7 \pm 0.2$ & - \\
& & $2900 \pm 271$ & $14.4 \pm 0.1$ & \\
A0, $0-14$ & $5.2 \pm 1.7$ & Soil Profile 2D-2019 & & $10140 \pm 507$ \\
AY, $14-26$ & $17.9 \pm 4.5$ & $3481 \pm 1408$ & $17.7 \pm 0.2$ & - \\
C, $26-60$ & $12.5 \pm 0.7$ & $3608 \pm 1798$ & $16.3 \pm 0.2$ & - \\
\hline
\end{tabular}
mean \pm standard deviation, $\mathrm{n}=6$

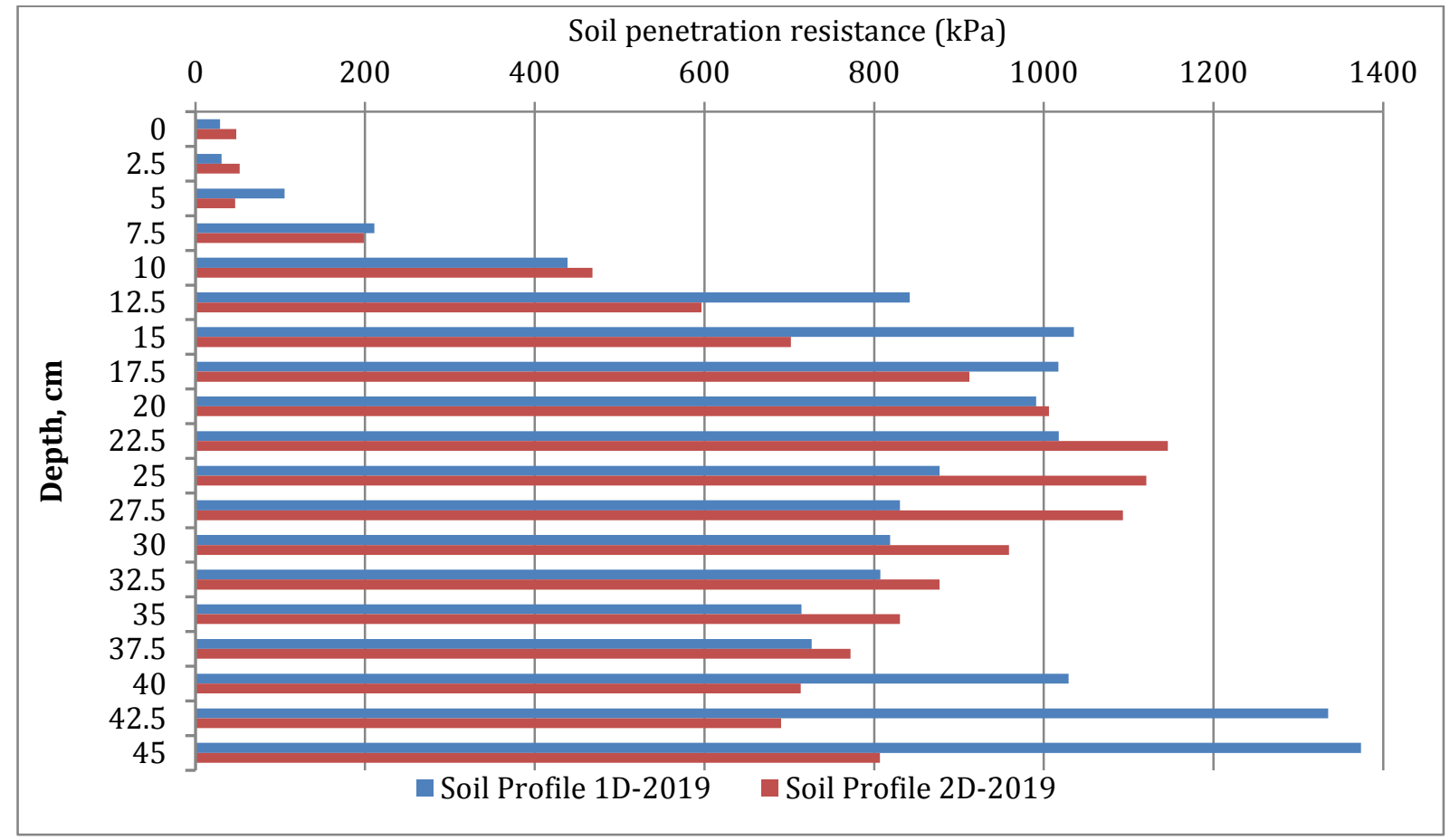

Figure 3. Vertical distribution of soils penetration resistance

More significant changes occurred in the chemical properties of the soil. At the post-hurricane site due to active form of the sod layer, there was an increase in the content of organic carbon in comparison with the site under the forest in the AY horizon by 1.1 times, alkaline hydrolyzable nitrogen by 1.6 times and available phosphorus by 1.2 times. At the same time, in the most sod horizon, the Corg content was $27,3 \mathrm{~g} \mathrm{~kg}^{-1} \mathrm{soil}_{\text {, }}$ alkaline hydrolyzable nitrogen - 252 and available phosphorus $46 \mathrm{mg} \mathrm{kg}-1$ soil (Table 5). 
Table 5. Chemical properties of soils

\begin{tabular}{|c|c|c|c|c|}
\hline \multirow{2}{*}{ Horizon, depth, cm } & \multirow{2}{*}{$\mathrm{pH}_{\mathrm{H} 2 \mathrm{O}}$} & Total organic carbon & $\mathrm{N}$ alkaline hydrolyzable & $\mathrm{P}_{2} \mathrm{O}_{5}$ available \\
\hline & & $\mathrm{g} \mathrm{kg}^{-1}$ soil & \multicolumn{2}{|c|}{$\mathrm{mg} \mathrm{kg}^{-1}$ soil } \\
\hline \multicolumn{5}{|c|}{ Soil Profile 1D-2019 } \\
\hline AY, 4-16 & $5.7 \pm 0.08$ & $22.6 \pm 1.2$ & $70 \pm 6.3$ & $24 \pm 4.4$ \\
\hline C, $16-50$ & $6.0 \pm 0.09$ & $12.7 \pm 0.8$ & $28 \pm 3.4$ & $28 \pm 2.2$ \\
\hline \multicolumn{5}{|c|}{ Soil Profile 2D-2019 } \\
\hline AO, $0-14$ & $5.4 \pm 0.07$ & $27.3 \pm 1.5$ & $252 \pm 8.4$ & $46 \pm 4.3$ \\
\hline AY, 14-26 & $5.6 \pm 0.08$ & $24.4 \pm 1.3$ & $112 \pm 8.7$ & $28 \pm 2.8$ \\
\hline$C, 26-60$ & $6.2 \pm 0.09$ & $10.4 \pm 1.8$ & $14 \pm 3.3$ & $57 \pm 2.4$ \\
\hline
\end{tabular}

mean \pm standard deviation, $\mathrm{n}=6$

The value of specific electrical resistivity is an indicator that depends on various processes of soil formation and a wide range of soil properties (Pozdnyakov, 2008; Alekseev et al., 2017). Thereby, it is possible to assume that increase of this indicator in humus-accumulative horizons in the profile of post-hurricane soil in 5,2 times was influenced by an increase of organic matter and nutrients content.

\section{Conclusion}

The pine forest areas damaged by the hurricane are undergoing strong transformation processes. Currently, in this area, there is an active formation of highly productive herbaceous vegetation and the renewal of deciduous stands. This resulted in an increase in biomass, which is confirmed by the analysis of NDVI results. Active development of grass vegetation leads to the formation of the sod horizon, not characteristic of the soil botanical monument of nature with a capacity of approximately $14 \mathrm{~cm}$, which contributes to the change and chemical properties of the soil. In humus-accumulation horizons, there is an increase in the content of organic carbon, alkaline hydrolyzable nitrogen and mobile phosphorus The electrical resistivity and acidification of the soil solution also increases.

\section{Acknowledgement}

This work was partly supported by the Russian Scientific Foundation: project № 17-16-01030 (laboratory study) and was performed within the framework of state assignment of the Ministry of Education and Science of the Russian Federation № 075-00326-19-00 on topic № AAAA-A18-118022190102-3.

\section{References}

Adamovich, T.A., Kantor, G.Ya., Ashikhmina, T.Ya., Savinykh, V.P. 2018. The analysis of seasonal and long-term dynamics of the vegetative NDVI index in the territory of the State Nature Reserve «Nurgush». Theoretical and Applied Ecology 1: 18-24. [in Russian].

Alekseev, I., Kostecki, J., Abakumov, E., 2017. Vertical electrical resistivity sounding (VERS) of tundra and forest tundra soils of Yamal region. International Agrophysics 31: 1-8.

Arinushkina, E.V., 1970. Soil chemical analysis guide. Moscow State University, Moscow, Russia. 488 p. [in Russian].

Baker, C., Sterling, M., Jesson, M., 2020. The lodging of crops by tornadoes. Journal of Theoretical Biology 500: 110309.

Barrett, B.S., Marin, J.C., Jacques-Coper, M., 2020. A multiscale analysis of the tornadoes of 30-31 May 2019 in southcentral Chile. Atmospheric Research 236: 104811.

Beck, H.E., Zimmermann, N.E., McVicar, T.R., Vergopolan, N., Berg, A., Wood, E.F., 2018. Present and future KöppenGeiger climate classification maps at 1-km resolution. Scientific Data 5: 180214.

Cadastral report on protected areas natural monument of regional importance «Pine forest near Venetsiya village», 2019. Information and analytical system «Specially Protected Natural Areas of Russia». Available at [Access date: 16.10.2020]: http://oopt.aari.ru [in Russian].

Chakraborty, A., Seshasai, M.V.R., Reddy, C.S., Dadhwal, V.K., 2018. Persistent negative changes in seasonal greenness over different forest types of India using MODIS time series NDVI data (2001-2014). Ecological Indicators 85: 887-903.

Chernetskiy, M., Pasko, I., Shevyrnogov, A., Slyusar, N., Khodyayev, A., 2011. A study of forest vegetation dynamics in the south of the Krasnoyarskii Krai in spring. Advances in Space Research 48: 819-825.

Chernokulsky, A., Shikhov, A., 2018. 1984 Ivanovo tornado outbreak: Determination of actual tornado tracks with satellite data. Atmospheric Research 207: 111-121.

Cui, W., Caracoglia, L., 2019. A new stochastic formulation for synthetic hurricane simulation over the North Atlantic Ocean. Engineering Structures 199: 109597.

Czerepanov, S.K., 1995. Vascular plants of Russia and adjacent states (within the limits of the former USSR). World and Family-95 Ltd, Moscow, Russia. 992 p. [in Russian].

De Beurs, K.M., McThompson, N.S., Owsley, B.C., Henebry, G.M., 2019. Hurricane damage detection on four major Caribbean islands. Remote Sensing of Environment 229: 1-13. 
Diaz, J., Joseph, M.B., 2019. Predicting property damage from tornadoes with zero-inflated neural networks. Weather and Climate Extremes 25: 100216.

Ezer, T., 2020. The long-term and far-reaching impact of hurricane Dorian (2019) on the Gulf Stream and the coast. Journal of Marine Systems 208: 103370.

Fern, R.R., Foxley, E.A., Bruno, A., Morrison, M.L., 2018. Suitability of NDVI and OSAVI as estimators of green biomass and coverage in a semi-arid rangeland. Ecological Indicators 94: 16-21.

Hoffmann, P., Merker, C., Lengfeld, K., Ament, F., 2018. The Hamburg Tornado (7 June 2016) from the perspective of low-cost high-resolution radar data and weather forecast model. Atmospheric Research 211: 1-11.

Kadilnikov, I.P., 1964. Physiographic zoning of Bashkir ASSR. Bashkir State University, Ufa, Bashkortostan. 191p. [in Russian].

Kopecký, K., Hejný, S., 1974. A new approach to the classification of anthropogenic plant communities. Vegetatio 29: 1720.

Long, J.A., Stoy, P.C., Gerken, T., 2018. Tornado seasonality in the southeastern United States. Weather and Climate Extremes 20: 81-91.

Majidzadeh, H., Uzun, H., Chen, H., Bao, S., Tsui, M.T.K., Karanfil, T., Chow, A.T., 2020. Hurricane resulted in releasing more nitrogenous than carbonaceous disinfection byproduct precursors in coastal watersheds. Science of The Total Environment 705: 135785.

Meixler, M.S., 2017. Assessment of Hurricane Sandy damage and resulting loss in ecosystem services in a coastal-urban setting. Ecosystem Services 24: 28-46.

Mo, Y., Kearney, M.S., Turner, R.E., 2020. The resilience of coastal marshes to hurricanes: The potential impact of excess nutrients. Environment International 138: 105409.

Moore, T.W., 2017. On the temporal and spatial characteristics of tornado days in the United States. Atmospheric Research 184: 56-65.

Novais, S., Sáyago, R., Cristóbal-Perez, E.J., Salguero-Hernández, G., Martén-Rodríguez, S., Lopezaraiza-Mikel, M., Quesada, M., 2020. Anthropogenic and hurricane disturbances had similar negative effects on epiphytic Tillandsia species in a tropical dry forest. Forest Ecology and Management 458: 117797.

Peng, W., Kuang, T., Tao, S., 2019. Quantifying influences of natural factors on vegetation NDVI changes based on geographical detector in Sichuan, western China. Journal of Cleaner Production 233: 353-367.

Pisek, J., Rautiainen, M., Nikopensius, M., Raabe, K., 2015. Estimation of seasonal dynamics of understory NDVI in northern forests using MODIS BRDF data: Semi-empirical versus physically-based approach. Remote Sensing of Environment 163: 42-47.

Pisman, T.I., Botvich, I.Yu., Shevyrnogov, A.P., 2018. Assessment of the state of forest vegetation in Krasnoyarsk Territory (Stolby Nature Reserve) according to satellite data. Sovremennye Problemy Distantsionnogo Zondirovaniya Zemli Iz Kosmosa 15: 130-140. [in Russian].

Pozdnyakov, A.I., 2008. Electrical parameters of soils and pedogenesis. Eurasian Soil Science 41: 1050-1058.

Riihimäki, H., Heiskanen, J., Luoto, M., 2017. The effect of topography on arctic-alpine aboveground biomass and NDVI patterns. International Journal of Applied Earth Observation and Geoinformation 56: 44-53.

Sahoo, B., Jose, F., Bhaskaran, P.K., 2019. Hydrodynamic response of Bahamas archipelago to storm surge and hurricane generated waves - A case study for Hurricane Joaquin. Ocean Engineering 184: 227-238.

Santoro, J.A., D'Amato, A.W., 2019. Structural, compositional, and functional responses to tornado and salvage logging disturbance in southern New England hemlock-hardwood forests. Forest Ecology and Management 444: 138150.

Shikhov, A., Chernokulsky, A., 2018. A satellite-derived climatology of unreported tornadoes in forested regions of northeast Europe. Remote Sensing of Environment 204: 553-567.

Shirokikh, P.S., Suleymanov, R.R., Kotlugalyamova, E.Yu., Martynenko V.B., 2017. Changes in the vegetation and soil cover after the windfall in the broad-leaved forest of the National park «Bashkiria». In: Proceedings of the RAS Ufa Scientific Centre 3(1): 214-220. [in Russian].

Sokolov, A.V. (Ed.), 1975. Agrochemical Methods of Soil Studies. Nauka, Moscow, Russia. 656 p. [in Russian].

Strader, S.M., Ashley, W.S., Pingel, T.J., Krmenec, A.J., 2018. How land use alters the tornado disaster landscape. Applied Geography 94: 18-29.

The Red Book of the Republic of Bashkortostan, 2011. Media Print, Ufa, Bashkortostan. 384 p. [in Russian].

The Register of especially protected natural territories of republican importance of Bashkortostan Republic, 2016. Belaya reka, Ufa, Bashkortostan. 400 p. [in Russian].

Tucker, R., Callaham, J.A., Zeidler, C., Paul, A.-L., Ferl, R.J., 2020. NDVI imaging within space exploration plant growth modules - A case study from EDEN ISS Antarctica. Life Sciences in Space Research 26: 1-9.

Weber, H.E., Moravec, J., Theurillat, J.-P., 2000. International Code of Phytosociological Nomenclature. 3rd edition. Journal of Vegetation Science 11: 739-768.

Westhoff, V., Van Der Maarel, E., 1978. The Braun-Blanquet Approach. In: Classification of Plant Communities. Whittaker, R.H. (Ed.), Springer Netherlands, Dordrecht, pp. 287-399.

Zhu, X., Liu, D., 2015. Improving forest aboveground biomass estimation using seasonal Landsat NDVI time-series. ISPRS Journal of Photogrammetry and Remote Sensing 102: 222-231. 